\title{
A rare case of clostridium septicum mycotic aortic arch aneurysm following open right hemicolectomy for colorectal cancer
}

\author{
Hasan Imam Al Hadi, ${ }^{1}$ Gaural Patel, ${ }^{2}$ Michael David Rees ${ }^{3}$
}

1 Department of General Surgery, Glan Clywd Hospital, Rhyl, Denbighshire, UK ${ }^{2}$ Department of General Surgery, Cardiff University, Abergavenny, UK ${ }^{3}$ Department of General Surgery, Wrexham Maelor Hospital, Wrexham, UK

\section{Correspondence to}

Gaural Patel,

gauralpatel2@gmail.com

Accepted 9 September 2014
CrossMark

To cite: Hadi HIA, Patel G, Rees MD. BMJ Case Rep Published online: [please include Day Month Year] doi:10.1136/bcr-2014204636

\section{DESCRIPTION}

A previously fit and well 63-year-old man, developed fever $\left(38^{\circ} \mathrm{C}\right)$ on third postoperative day following an uncomplicated (no haemorrhage or faecal spillage) elective, open right hemicolectomy for a Dukes B pT3N0M0 tumour. Physical examination revealed bilateral lung crepitations and a nontender abdomen. Routine bloods and a blood culture were sent. A chest radiograph was performed which revealed a widened mediastinum (figure 1). Owing to this finding an urgent CT angiogram was performed which revealed a $7.2 \mathrm{~cm}$ aneurysmal dilation of the aortic arch, extending to the mid-thoracic aorta, with gas seen within the wall of the aorta (figures 2 and 3). Comparison with the patient's preoperative staging CT 6 weeks

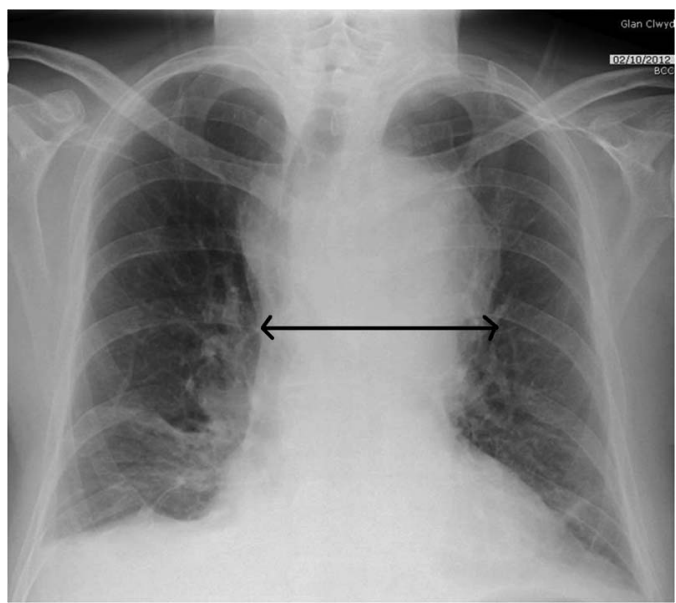

Figure 1 Chest radiograph revealed a widened mediastinum.

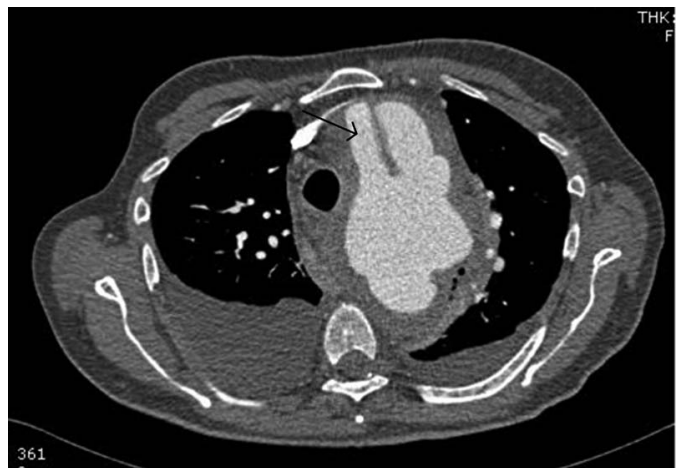

Figure $2 \mathrm{CT}$ angiogram showing aneurysm of aortic arch and descending thoracic aorta, with gas seen within the wall of the aorta. ago revealed none of these changes (figure 4). The case was discussed with the regional cardiothoracic unit and immediate transfer was arranged. Unfortunately the patient died soon after arrival following a decision that surgical repair was not feasible given the extent of disease and the patients deteriorating condition. Blood cultures taken would later grow Clostridium septicum.

C. septicum is a Gram positive, spore-forming bacterium. It remains a rare cause of perioperative sepsis in patients with colorectal malignancy. There are some reports recently of C. septicum infection causing mycotic aneurysms resulting in high mortality. ${ }^{1}{ }^{2}$ A number of case series has suggested a link between C. septicum infection and malignancy. ${ }^{3}$ This is the first report to our knowledge of

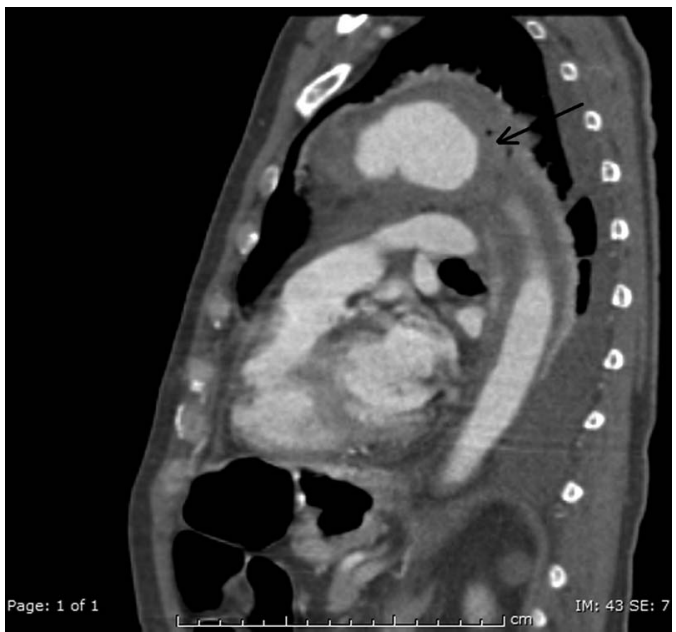

Figure $3 \mathrm{CT}$ angiogram showing aneurysm of aortic arch and descending thoracic aorta, with gas seen within the wall of the aorta.

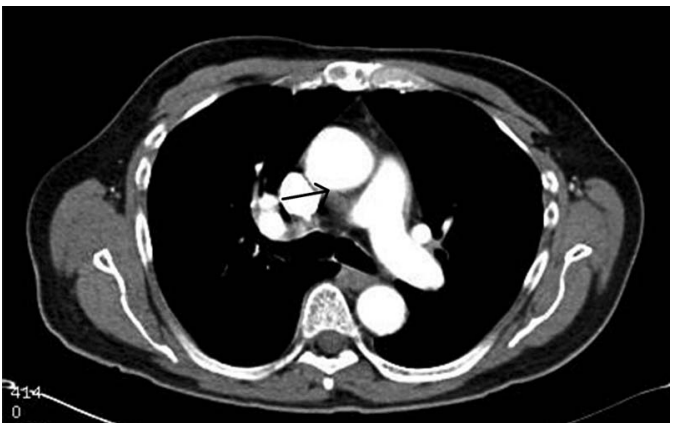

Figure 4 Preoperative staging CT showing normal aortic arch. 
a mycotic aneurysm following C. septicum infection complicating the postoperative course of a right hemicolectomy. Early suspicion, diagnosis and prompt treatment are key to improve outcome, although mortality remains high.

\section{Learning points}

- Clostridium septicum is present in the normal human intestinal flora.

- C. septicum infections are associated with colonic or haematological malignancy.

- Although mycotic aneurysm following C. septicum infection is rare a high index of suspicion is needed for the diagnosis.

- Antibiotics and surgical treatment remains the mainstay of treatment.
Acknowledgements The authors would like to thank the Glan Clywd radiology department for help with formatting the images.

Contributors HIAH operated on and treated the patient. He also reviewed the final manuscript. GP and MDR researched and wrote up the case report.

Competing interests None.

Patient consent None.

Provenance and peer review Not commissioned; externally peer reviewed.

\section{REFERENCES}

1 Seder CW, Kramer $\mathrm{M}$, Long $\mathrm{G}$, et al. Clostridium septicum aortitis: report of two cases and review of the literature. J Vasc Surg 2009;49:1304-9.

2 Yang Z, Reilly SD. Clostridium septicum aortitis causing aortic dissection in a 22-year-old man. Tex Heart Inst I 2009;36:334-6.

3 Katlic MR, Derkac WM, Coleman WS, et al. Clostridium septicum infection and malignancy. Ann Surg 1981;193:361-4.

Copyright 2014 BMJ Publishing Group. All rights reserved. For permission to reuse any of this content visit http://group.bmj.com/group/rights-licensing/permissions.

BMJ Case Report Fellows may re-use this article for personal use and teaching without any further permission.

Become a Fellow of BMJ Case Reports today and you can:

- Submit as many cases as you like

- Enjoy fast sympathetic peer review and rapid publication of accepted articles

- Access all the published articles

- Re-use any of the published material for personal use and teaching without further permission

For information on Institutional Fellowships contact consortiasales@bmjgroup.com

Visit casereports.bmj.com for more articles like this and to become a Fellow 